\title{
7. Women, authority and power on Ramahyuck Mission, Victoria, 1880-1910
}

\author{
Joanna Cruickshank and Patricia Grimshaw
}

By the late nineteenth century, Christian missions in the Colony of Victoria, as in many other settler colonies, had become central to the governance of Indigenous people. While missionaries generally saw their aims as distinct from those of the settler administration, in practice missions provided a focus for colonial efforts to control and assimilate Aboriginal people. Missions are thus central to the task of understanding colonial governance and its impact on Indigenous people in Australia. Voluminous mission and bureaucratic archives, containing records produced by missionaries, colonial administrators and Aboriginal mission residents, provide rich sources for analysing how colonial policies towards Indigenous people were implemented and experienced 'on the ground'.

These sources make clear that while missions became locations where the authority of the settler colonial state was extended over the country, bodies and families of Indigenous people, they were also sites of intimate relationships, shifting power balances and complex interdependencies. For both ideological and practical reasons, missionaries were rarely willing or able to act simply as extensions of state power. Their role within the colonial bureaucracy also varied over time and from place to place. For their part, Aboriginal people negotiated a tangled and often oppressive web of colonial regulations, mission politics and personal loyalties to maintain themselves and their families.

This chapter explores this complex situation through the lives of four women who lived on Victorian missions in the late nineteenth and early twentieth centuries. It considers how colonial authority was wielded on the mission and how power was experienced in people's lives. We focus particularly on women, both Indigenous and non-Indigenous, because they had little official authority within the structures of the colonial state or missionary organisations and their voices are rarely heard in official mission records. Nonetheless, they were not without influence.

Postcolonial and feminist scholarship has given us a language for talking about the choices and experiences of those who are oppressed by colonialism and by patriarchy. Terms such as 'agency', 'resistance' and 'negotiation', combined with the method of reading historical sources 'against the grain' have helped us to understand and express how people preserved the capacity to make some 
choices while experiencing oppressions that severely curtailed their liberties. This chapter stands within this tradition of scholarship. ${ }^{1}$ However, valuable as such approaches are, we would argue that they can result in the interpretation of all experiences, actions and relationships purely in terms of a hierarchy of oppressive power relations. For all the power of colonialism in people's lives, their lives were not simply about colonialism. This is, of course, particularly true of Indigenous people, whose stories have so often been distorted and ignored by the records of the colonial state. In this chapter we adopt in part a biographical approach because narratives of lives help us to see the other powerful realities in people's lives - such as family, friendship and spirituality - as well as the interactions between the mechanisms of settler colonialism and these other aspects of life.

In this chapter we tell the stories of two Indigenous women - Emily Milton Stephen and her daughter Maud Stephen Mullett, who lived for many years at Ramahyuck Mission - and two non-Indigenous women - Louise Hagenauer, wife of the missionary manager at Ramahyuck, and her daughter, Ellie Hagenauer Le Souëf. The Stephen and Hagenauer families spent much of their lives at the Ramahyuck Mission on Gunai country in south-eastern Victoria. The mission was established in 1862 by German Moravian missionaries, Friedrich and Louise Hagenauer, with the support of the Presbyterian Church of Victoria. For many years, Ramahyuck was the largest mission in Victoria and its manager, Friedrich Hagenauer, became accepted as an expert on Indigenous matters within the colonial bureaucracy. He supported the implementation of the Aborigines Protection Act 1886 (Vic) (the infamous 'Half-Caste Act') and was appointed secretary of the Board for Protection of Aborigines (BPA) in 1889. He also advised on the development of missions in other Australian colonies, particularly the north Queensland missions of Mapoon and Aurukun.

Not surprisingly, then, Ramahyuck Mission has received attention from historians. Ramahyuck provides the central case study for Bain Attwood's discussion of the role of missions in his influential book, The Making of the Aborigines. ${ }^{2}$ Felicity Jensz has provided a detailed study of the role of German Moravians, including the Hagenauers, in establishing missions in Victoria. ${ }^{3}$ She has also analysed issues relating to the education of children at Ramahyuck, through a study of the colonial education department archives. ${ }^{4}$ Robert Kenny's

\footnotetext{
1 For example, Ann Laura Stoler, Carnal Knowledge and Imperial Power: Race and the Intimate in Colonial Rule, University of California Press, Berkeley and Los Angeles, 2002; Anne McClintock, Imperial Leather: Race, Gender and Sexuality in the Colonial Context, Routledge, New York, 1995.

2 Bain Attwood, The Making of the Aborigines, Allen \& Unwin, Sydney, 1989.

3 Felicity Jensz, Moravian Missionaries in the British Colony of Victoria, Australia, 1848-1908: Strangers in a Strange Land, Studies in Christian Missions, 38, Brill, Leiden, 2010.

4 Felicity Jensz, "'In future only female teachers": staffing the Ramahyuck Mission school in the nineteenth century', Provenance: The Journal of Public Record Office Victoria 11, 2012. http://prov.vic.gov.au/ publications/provenance/in-future-only-female-teachers.
} 
award-winning book on the Aboriginal convert Nathaniel Pepper, The Lamb Enters the Dreaming, though it deals primarily with the period before the establishment of Ramahyuck, pays close attention to Pepper's relationship with Hagenauer. ${ }^{5}$ John Harris and Aldo Massola also discuss Ramahyuck in their more general overviews of mission history. ${ }^{6}$

These accounts of the mission tend to rely heavily on archival sources authored by Friedrich Hagenauer, or by other settler officials and missionaries. Ramahyuck was a Presbyterian Church mission, run by German Moravian missionaries and receiving funds from the colonial government. Hagenauer thus had to report to three bodies - the Presbyterian Church of Victoria, the Moravian bishops in Germany and the BPA. Many of his reports and official correspondence have been preserved. ${ }^{7}$ Other sources provide a more personal perspective on the mission, from both an Indigenous and non-Indigenous perspective. These include published sources, such as the accounts of Ramahyuck history given by Aboriginal elder, Phillip Pepper, and the letters of Aboriginal women at Ramahyuck to the BPA. ${ }^{8}$ They also include a wealth of unpublished material in the papers of Ellie Hagenauer Le Souëf, consisting of her diaries and correspondence written during and after her years at Ramahyuck. ${ }^{9}$ Through this diversity of sources it is possible to reconstruct a more nuanced picture of the experiences of those who lived at Ramahyuck, particularly the stories of the women who are being considered in this chapter. We focus particularly on their experiences at Ramahyuck until its closure in 1909, but we also examine their lives after leaving Ramahyuck as reflected in these sources.

Louise Hagenauer, the oldest of the four, was born Christiana Louise Knobloch in Saxony in March 1834. In a letter written towards the end of her life, she recounted how she had joined the Moravian movement at the age of 12. After overcoming some resistance from her parents, she moved to the Moravian

5 Robert Kenny, The Lamb Enters the Dreaming: Nathanael Pepper and the Ruptured World, Scribe, Melbourne, 2007.

6 John Harris, One Blood: 200 Years of Aboriginal Encounter with Christianity, A Story of Hope, Albatross Books, Sutherland, NSW, 1990; Aldo Massola, Aboriginal Mission Stations in Victoria, Hawthorn Press, Melbourne, 1970.

7 Key collections of this material include 'Letterbooks of R. A. Hagenauer, 1865-1885', MS 3343, National Library of Australia, Canberra (henceforth, 'Letterbooks', NLA); 'Moravian Mission Papers' MF 163-179, Australian Institute of Aboriginal and Torres Strait Islander Studies, Canberra (henceforth, 'Moravian Mission Papers', AIATSIS); and the published Proceedings of the General Assembly of the Presbyterian Church of Victoria, Uniting Church Archives, Melbourne (henceforth, Proceedings of the General Assembly).

8 Phillip Pepper and Tess de Araugo, The Kurnai of Gippsland, What Did Happen to the Aborigines of Victoria, vol. 1, Hyland House, Melbourne, 1985; Phillip Pepper, You Are What You Make Yourself to Be: The Story of a Victorian Aboriginal Family, Hyland House, Melbourne, 1980; Elizabeth Nelson, Sandra Smith and Patricia Grimshaw (eds), Letters from Aboriginal Women of Victoria, 1867-1926, History Department, University of Melbourne, Melbourne, 2002.

9 Ellie Hagenauer Le Souëf's diaries and correspondence are held with the Le Souëf Family Papers, MN 1391, Battye Library, Western Australia (henceforth Le Souëf, WA). Permission to access and quote from the Le Souëf Family Papers has very kindly been given by Marjorie Le Souëf. 
community, where she lived like all Moravian children in a dormitory and rarely saw her own parents or siblings. ${ }^{10}$ The Moravian movement was characterised by a commitment to missionary work around the world and on reaching adulthood, Louise offered herself for this task. She was chosen by lot to marry Friedrich Hagenauer, who had already left for Australia. She followed him and on 15 June 1861 at St Paul's Church, Melbourne, she married him. The couple had nine children, seven of whom were born at Ramahyuck.

Emily Stephen was a Gunai woman, born Emily Wood around 1860. She was brought to Ramahyuck at the age of nine in circumstances that are unclear. ${ }^{11}$ Emily was employed as a nurse to some of the Hagenauer children, including their daughter Ellie. She was educated in the Ramahyuck school and acted for many years as teaching assistant at the school. Emily married another Ramahyuck resident, Harry Stephen, and the couple had 11 children. In later years, she sought a living away from Ramahyuck and also spent time living at Lake Tyers mission. ${ }^{12}$

Ellie Hagenauer was born at Ramahyuck in 1873. She was educated at Ramahyuck for her primary schooling and was then sent to Melbourne to attend the Presbyterian Ladies' College. After finishing high school in 1891, she returned to the mission and assisted her parents. In 1899, she married Ernest Le Souëf, son of Albert Le Souëf, who founded the Melbourne Zoo. She moved with her husband to Perth, where he established a zoo and she became involved in a number of charitable causes. The couple had four children. ${ }^{13}$

Emily's oldest daughter, Maud Stephen, was born at Ramahyuck in 1881. She grew up on the mission and worked for some years in Melbourne caring for the children of the Hagenauers' oldest daughter, Ida. She later married Dave Mullett, who had grown up at the Lake Condah reserve. The couple, who had nine children, lived for some years in the Melbourne suburb of Carlton. Her husband enlisted in the Australian Army during World War I and served in the Middle East. After his return, the family were moved to the Lake Tyers mission. ${ }^{14}$

The writings of these four women allow a closer analysis of their lives on the mission, their relationships with each other and the broader power structures

\footnotetext{
10 Louise Hagenauer to Ellie Le Souëf, 30 June 1914, 4370A 713/9, Le Souëf, WA.

11 Emily Stephen to Louise Hagenauer, nd [c.1908 from internal evidence], 4370A/479, Le Souëf, WA.

12 See Patricia Grimshaw, “That we may obtain our religious liberty...": Aboriginal women, faith and rights in early twentieth century Victoria, Australia', Journal of the Canadian Historical Association / Revue de la Société historique du Canada 19(2), 2008: 39-40.

13 A brief overview of Ellie's life, with a focus on her years in Perth, is given in Noel Stewart, 'Mrs Ellie Grace Le Souëf (1873-1947): She helped to found a zoo', in As I Remember Them, Artlook Books, Perth, 1987: 103-108.

14 See Grimshaw, 'That we may obtain our religious liberty...': 35, 41.
} 
within colonial society. Louise founded the mission with Friedrich, in a situation remote from white settlement. In old age, she wrote to her daughter: 'No need for me to say I felt it hard, especially to be so much alone with the natives, which were very cruel sometimes, but I had a strong nature and not easily frightened.' ${ }^{15}$ In addition to giving birth to nine children, she was involved in the establishment and maintenance of the mission, performing domestic labour and training Aboriginal women in European domestic skills. She conducted sewing lessons for the adult women, while school-aged girls were taught 'sewing, washing, mending, housework and ironing etc. ${ }^{16}$ She nursed the Indigenous and non-Indigenous residents in times of sickness and in old age. The mission residents called her yuccan, the Gunai word for mother. ${ }^{17}$

Friedrich Hagenauer's reports often describe the responsibility for the mission in the first person plural, commenting, for example, that 'The general oversight is, of course, in our own hands.' ${ }^{\prime 1}$ This may well have reflected a Moravian understanding of mission, in which both men and women were understood to share the missionary task. It was, however, Friedrich who was employed as manager at Ramahyuck and he saw the mission as ultimately his responsibility. When he visited north Queensland in 1885, on a trip to identify locations for a new mission there, he reassured the Presbyterian Missions board:

The work at Ramahyuck, during my absence, was carried on as usual. Mr Beilby kindly took the services; my eldest son, the farming and station work; my eldest daughter, the Government part; of course, all under the direction of Mrs Hagenauer, so that on my return, I found all in best working order. ${ }^{19}$

Historians have generally followed Friedrich's lead in focusing primarily on his role on the mission. Yet this view can obscure both the complexity of the power dynamics on the mission and the practical realities of mission life.

By the late 1880s, life on the mission had changed. The passing of the 1886 'Half-Caste Act', which removed all younger Indigenous people of mixed descent from the mission, meant that the number of mission residents dropped significantly. In 1889, Friedrich took on the role of Secretary of the BPA and was hardly at the mission during the week. In his absence, Louise undertook most of the day-to-day running of the mission. Friedrich's official reports do not make

15 Louise Hagenauer to Ellie Le Souëf, 30 June 1914, 4370A 713/9, Le Souëf, WA.

16 Report on 'Aboriginal Mission Station, Ramah Yuck, Gipps Land', Proceedings of the General Assembly (1871): 69.

17 Pepper, You are What You Make Yourself to Be: 10.

18 Report on 'Aboriginal Mission Station, Ramah Yuck, Gipps Land', Proceedings of the General Assembly (1881): xxiii (emphasis added).

19 Report on 'Aboriginal Mission Station, Ramah Yuck, Gipps Land', Proceedings of the General Assembly (1885): xx. 
this division of labour clear, but it emerges as a source of significant tension in Ellie's diary. In 1893, she commented: 'I am too sorry for Mother having so much to do ... Poor Mother has a very hard life, never gets a grain of credit but is always looked upon as a well I can't say the word, I am so indignant ${ }^{\prime} .^{20}$ Where historians have depicted Friedrich as an autocratic figure, Ellie wrote in 1896: 'I wish Papa were as firm as Mother in keeping his threats, but Papa is soft \& can't bear to punish $-\&$ so the natives never believe what is said to them.' ${ }^{21}$

As this situation demonstrates, European gender norms meant that while missionary wives were often in the background of mission reports, in practice they could assume substantial responsibility for mission management. ${ }^{22}$ Yet the official structures of missions meant that their power in this role was constrained; ultimately, the decision of the husband would be considered final by external authorities. Missionaries and Aboriginal people lived in close proximity, which meant that Aboriginal people were undoubtedly aware of this potential tension and could exploit it. Ellie's diary suggests that during the late 1880s and 1890s, mission residents whom Louise attempted to coerce or punish would wait until Friedrich came home and convince him to overrule Louise's decisions. Ellie noted with frustration in one such situation: 'Mother who manages the station should have her word \& authority upheld and not always have the disagreeables.' ${ }^{23}$

Emily, too, had some official authority on the mission during this period. As noted, at times she acted as teaching assistant at the school, making her one of the few Aboriginal people with a formal role in the Ramahyuck hierarchy. Felicity Jensz has traced the history of the school at Ramahyuck, which became a government school in 1871 and received consistently excellent results in the annual inspections by the Department of Education. ${ }^{24}$ Emily was assisting at the school during part of this period, but from 1901, after the population of the mission had declined considerably, the school reverted to the control of the mission, and Emily had sole responsibility for educating the children until 1905. ${ }^{25}$ Her authority was, of course, profoundly contingent upon the Hagenauers. Her interactions with the Hagenauer women, as described in Ellie's diary, provide evidence of the complicated nature of such relationships between missionaries and Indigenous people whom they perceived as allies.

\footnotetext{
20 4-14 January 1893, Diary of Ellie Hagenauer, 4370A/634, Le Souëf, WA.

2123 March 1896, Diary of Ellie Hagenauer, 4370A/637, Le Souëf, WA.

22 This was true on other late nineteenth-century missions such as the Manunka mission in South Australia, which was putatively run by Daniel and Janet Mathews, but in practice run almost entirely by Janet. See Patricia Grimshaw, 'Rethinking approaches to women and missions: the case of colonial Australia', History Australia 8(3), December 2011: 7-24.

2327 March 1896, Diary of Ellie Hagenauer, 4370A/637, Le Souëf, WA.

24 Jensz, 'In future only female teachers'.

25 Jensz, 'In future only female teachers': 12.
} 
In 1894, Ellie recorded tension between her parents over the behaviour of her younger brothers, who had committed some unspecified misdemeanour. In the absence of her father in Melbourne, she noted that her mother was working herself to exhaustion and commented: 'Poor Mother is blamed for the misdemeanours of the boys by both Alf [her older brother] and Papa. ${ }^{26}$ Shortly afterwards, she wrote: 'Emily Steven [sic] helped me in the house, she was very good. She and Mother had a long talk over things in general. The things Donald says about the boys are horrible \& it troubles Mother. ${ }^{27}$ In this situation, overworked and troubled by criticism of her sons by Donald (Cameron), an Aboriginal mission resident, Louise clearly looked to Emily for both emotional and practical support. This was not without cost to Emily, however. Ellie noted a week later that Emily's children were 'very cross' about Emily helping in the Hagenauer home again. ${ }^{28}$

As this small incident suggests, missionaries relied on trusted mission residents for practical and emotional support within the often conflict-ridden life of the mission. In addition, they depended to some degree on Aboriginal cooperation for their authority within settler society as a whole. Mission managers who completely alienated mission residents could find themselves the focus of external scrutiny and even, in the case of the Coranderrk reserve, an official enquiry. ${ }^{29}$ By contrast, missionaries could strengthen their own authority by demonstrating support from mission residents.

In 1892, for example, two new teachers, Miss Vidler and Miss Moss, were appointed to the Ramahyuck school by the Education Department. ${ }^{30}$ Conflict quickly developed between the Hagenauers and the teachers, whom Ellie referred to derisively as the 'Pilgrims', apparently because of their sense of religious superiority. ${ }^{31}$ According to Ellie, in a series of confrontations with Louise, Emily and Ellie, Vidler and Moss claimed that the mission was no longer a Christian mission: 'it was once a [Christian] mission, but love of money \& pride of worldly position came in \& took away the love of Christ. ${ }^{32}$ Emily was a central participant in this conflict. She withdrew her children from the school in late February and wrote to the teachers to defend her decision. 'I don't think it right or just to say to the children that Mr Hagenauer is a wicked man', she wrote,

\footnotetext{
2611 February 1894, Diary of Ellie Hagenauer, 4370A/635, Le Souëf, WA.

275 March 1894, Diary of Ellie Hagenauer, 4370A/635, Le Souëf, WA.

2812 March 1894, Diary of Ellie Hagenauer, 4370A/635, Le Souëf, WA.

29 For the Coranderrk inquiry see Diane Barwick, Rebellion at Coranderrk, Laura E. Barwick and Richard E. Barwick (eds), Aboriginal History Inc, Canberra, 1998.

30 Jensz has given a brief account of this affair from the perspective of the Education Department records in 'In the future only female teachers': 8-9.

31 See entries for February-March 1892, Diary of Ellie Hagenauer, 4370A/633, Le Souëf, WA. It seems likely that they were members of the Salvation Army, as Ellie mentions that she offended them by laughing about the Salvation Army.

328 March 1892, Diary of Ellie Hagenauer, 4370A/633, Le Souëf, WA.
} 
'what is between you \& him has nothing to do with the children.' ${ }^{33}$ When the teachers accused the Hagenauers of mistreating Aboriginal children and misusing government funds, Emily wrote to local pastoralists to defend the Hagenauers against these charges. ${ }^{34}$ After the mission, children had been withdrawn from the school by their mothers, Hagenauer wrote to the Secretary of the Education Department to request that the teachers be replaced. He enclosed a petition from the mothers and the letter that Emily had written to the teachers. These documents, as evidence of the mission residents' wishes, were clearly intended to give authority to his own request that the teachers be removed. On $14 \mathrm{March}$, Ellie wrote in her diary: 'The Pilgrims left amidst loud hurrays \& flying flags 9 in all. Bessie rang the ration bell \& all the natives shouted for joy.' 35

The joint effort between the Hagenauers and the mission residents to remove Vidler and Moss is an example of the complicated alliance between the missionaries and the Aboriginal people on the mission. The mothers at the mission apparently withdrew their children from the school partly out of loyalty to the Hagenauers, whom the teachers had criticised. But according to the petition signed by the mothers, the teachers had also insulted the children as 'horrible nasty creatures' ${ }^{36}$ Emily wrote that by insulting the Hagenauers and 'all the people', the teachers had made the older children 'disobedient \& defiant'. She was withdrawing her children, she wrote, because she wished them 'to respect both Mr \& Mrs Hagenauer \& myself'.${ }^{37}$ This letter suggests that within the structures of the mission, Emily saw her own authority bound up with the Hagenauers, just as their authority was in part tied to her cooperation.

All this is not to suggest that the relationship between Emily and the Hagenauers was equitable. When describing the conflict with the teachers, Ellie noted that a non-Indigenous friend of hers, Colina, had accompanied Emily in her confrontations with the teachers: 'if Col had not been there Emily would have been bamboozled, the things were twisted round so very cleverly'. ${ }^{38}$ The assumption that Emily required a white 'witness' in order to stop her from being 'bamboozled' communicates very clearly the condescension that shaped many of the Hagenauers' interactions with mission residents.

33 Emily Stephen to Miss Vidler and Miss Moss, 25 February 1892, Item 1892/8131, VPRS 640/PO Central Inward Primary Schools Correspondence, Unit 657 School No. 1088, Public Records Office Victoria (henceforth, PROV).

34 Entries for March 1892, Diary of Ellie Hagenauer, 4370A/633, Le Souëf, WA.

3514 March 1892, Diary of Ellie Hagenauer, 4370A/633, Le Souëf, WA.

36 Petition signed by Bessy Cameron, Florance Moffat, Mary Scott, Emily M Stephen, Lulu Darby to J Broduble Esq, 27 February 1892, Item 1892/8131, VPRS 640/PO Central Inward Primary Schools Correspondence, Unit 657 School No. 1088, PROV.

37 Emily Stephen to Miss Vidler and Miss Moss, 25 February 1892, Item 1892/8131, VPRS 640/PO Central Inward Primary Schools Correspondence, Unit 657 School No. 1088, PROV.

389 March 1892, Diary of Ellie Hagenauer, 4370A/633, Le Souëf, WA. 
Ellie herself had no official authority at Ramahyuck, but while living at the mission after her return from school in Melbourne, she helped her mother with the housework and care of the sick, taught Sunday school and music to the children. On the rare occasion that her mother went on holiday, she would take on many of her roles, in particular supervision of the teenage girls, whose conduct was of concern to the missionaries. 'The girls are rather provoking', she wrote in April 1894, 'I must watch so constantly that they do not make love to the boys. ${ }^{39}$ The following year she lamented 'I hate to act "policeman" yet it is so necessary with the blacks. When Mother is away I dread the responsibilities, but if Mother knew my feelings she would never go \& so I can say nothing to her.' ${ }^{40}$ If her father was also absent, she could take on herself more substantial authority. In December 1894, for example, she 'lectured the natives for not coming to prayers - they must attend to the rules on the place'.$^{41}$ In 1897 , she noted that she 'spoke to' one of the Aboriginal men because he had beaten his wife and he had written to her promising not to do so in future. ${ }^{42}$ Ellie was a single woman in her early 20s, but she clearly understood herself as having the right to police (however reluctantly) Indigenous young women, 'lecture' Indigenous people much older than her and intervene in Indigenous marriages. Her behaviour demonstrates clearly how racial hierarchies structured the mission. Her power was, in some ways, limited. When, in her father's absence, two young Aboriginal people ran away from the mission together, she sent a telegram to her father to ask for advice. He responded that 'nothing could be done' ${ }^{43}$ Nonetheless, as representative of her parents, who in turn represented the colonial state, she acted in deeply paternalistic ways.

The power structures on the mission can be seen even more clearly in the experience of Maud Stephen. During the 1890s, Maud was one of the teenage girls whose sexuality so concerned the missionaries and over whom Ellie felt she had to 'act policeman'. In August 1895, Ellie noted that her mother was investigating 'all sorts of love affairs' on the mission. 'Maud is a naughty child', she continued, 'at 14 she commenced a matrimonial correspondence with Walter McCreedie. ${ }^{44}$ The following year, while Emily was away from the mission, Louise intercepted a letter that Maud had written to her mother. '[I]t was an impertinent letter, Maud is a little hypocrite ... Papa read Maud's letter to her, Louise Conolly \& Mother, \& Maud was shown herself in her true light. ${ }^{45}$

3913 April 1894, Diary of Ellie Hagenauer, 4370A/635, Le Souëf, WA.

4019 June 1895, Diary of Ellie Hagenauer, 4370A/635, Le Souëf, WA.

411 December 1894, Diary of Ellie Hagenauer, 4370A/635, Le Souëf, WA.

4230 September 1897, Diary of Ellie Hagenauer, 4370A/636, Le Souëf, WA.

4321 October 1892, Diary of Ellie Hagenauer, 4370A/633, Le Souëf, WA.

4423 August 1895, Diary of Ellie Hagenauer, 4370A/636, Le Souëf, WA.

45 6-7 April 1896, Diary of Ellie Hagenauer, 4370A/637, Le Souëf, WA. 
This scrutiny of Maud's correspondence - and the attempt to shame her in front of Louise Hagenauer and Louise Conolly (an older Indigenous resident) - is evidence of how intrusive the Hagenauers could be. In particular, in both these instances they saw it as their right to scrutinise and discipline Maud, rather than leave the matter to her parents, even though both Emily and Harry Stephen were mission residents. In the same month that Maud's letter was intercepted, Ellie wrote that the Hagenauers had read a letter from Emily to another woman on the mission in which Emily had apparently been critical of the Hagenauers. '[W]e found out again how very two-faced she is; Really it is difficult to manage a Station, here we do our best for the natives \& yet we know that they think anything but pleasantly of us. ${ }^{46}$ On an earlier occasion, Ellie had defended Emily against what she saw as 'unjust' accusations that her mother had made against Emily, but her primary loyalty was clearly with her family. ${ }^{47}$ While there might be a kind of intimacy and a level of interdependency, as well as affection, between these two pairs of mothers and daughters, there was also underlying resentment which at times boiled over into open hostility.

Small encounters between the four women, such as those considered above, are evidence of the complicated nature of their relationships with each other and their power - or lack of it - within the mission. Can such seemingly insignificant details shed light on broader questions of colonial governance and Indigenous people? For this, it is helpful to consider the longer story of these women's relationships, and their lives, which lasted beyond their years at Ramahyuck. In the remainder of the chapter we focus particularly on Emily Stephen, who maintained relationships with all three of the other women considered here, and whose voice and experience appears in unusual detail in the colonial archive.

By the late 1890s, numbers at Ramahyuck had declined steeply and many of the original mission residents had died or moved elsewhere. In 1899, Ellie Hagenauer married Ernest Le Souëf and left Ramahyuck for Perth. Maud Stephen asked Ellie if she could accompany them and work as their domestic servant. Ellie's discussion of this request in her letters to Ernest displays their shared anxiety about Aboriginal women's sexuality. He wrote that he had heard that in Western Australia 'half-caste' girls all 'go wrong' when grown up and Ellie responded that she would need to be very strict with Maud to stop her going astray. ${ }^{48}$ Ultimately, Maud went to work for Ellie's sister in Melbourne instead, but the following year Emily wrote to Ellie to say that Maud still 'had it in her head' to join Ellie if possible. ${ }^{49}$ In the five years following Ellie's departure, Emily

\footnotetext{
4629 April 1896, Diary of Ellie Hagenauer, 4370A/637, Le Souëf, WA.

4728 November 1894, Diary of Ellie Hagenauer, 4370A/635, Le Souëf, WA. According to this entry, Louise had 'words' with Emily for visiting a local settler who was critical of the Hagenauers.

48 See Ernest Le Souëf to Ellie Hagenauer, 2 December 1898; Ellie Hagenauer to Ernest Le Souëf, 23 December 1898, 4370A/232-239, Le Souëf, WA.

49 Emily Stephen to Ellie Hagenauer Le Souëf, 5 February 1900, 4370A/713/8/11, Le Souëf, WA.
} 
wrote to her regularly. Emily's letters describe life at Ramahyuck in familiar and domestic terms, passing on news about the mission residents and recounting her attendance at social events in the local town, Sale. She noted that around 72 Aboriginal people had attended the Sale Show in 1903, exclaiming 'don't you think that was a great gathering of coloured folk? I for my part enjoyed it very much, especially the flowers, some were just perfection ... the Scones home made, I pride myself I could have made better. ${ }^{50}$ During these years, Emily wrote often of her affection for and gratitude to Ellie and her family, referring to her former role as Ellie's nurse. When Ellie had her first child, Emily wrote to her:

And darling you have a dear little baby boy of your own I'm so happy I told mamma the other day that that was my little grannie also. I hope by now that you will be getting strong again, take care of yourself dear kiss your dear little baby for me. I would just love to see it \& hold it in my arms God bless \& keep you both darling you must excuse me how I call you but I do love you so much \& am always thinking of you. ${ }^{51}$

However, alongside such expressions of affection and accounts of social occasions, trips to camp in the bush and the progress of her garden was evidence of the many restrictions placed on her and other Aboriginal mission residents. All journeys away from Ramahyuck, even day trips, required the permission of Friedrich Hagenauer, as did visits from family members classified as 'half-castes' under the 1886 Act.

It was during these years between 1901 and 1904 that Emily was given the role of sole teacher at the school at Ramahyuck. In 1904, however, the school was closed and Emily left the mission with her younger children. The sequence of events that led to her leaving is unclear, but it appears that she left early in the year after conflict with the Hagenauers and with the intention of living outside of the mission system. In June of that year, however, she wrote to the vicechairman of the BPA, requesting that she and her children be allowed to return to Ramahyuck and occupy the cottage where they had lived previously. She was writing from Gippsland Hospital, where she had been for six weeks with tuberculosis, unable to work to support her children..$^{52}$ The vice-chairman, $\mathrm{Mr}$ Ditchburn, responded that by 'leaving Ramahyuck in the manner you did you forfeited all your claims'. Nonetheless, he conceded, he was sure she would be given her old privileges, 'provided you act and live differently than when you were previously at the station' ${ }^{53}$

50 Emily Stephen to Ellie Hagenauer Le Souëf, 14 November 1903, 4370A/713/8/13, Le Souëf, WA.

51 Emily Stephen to Ellie Hagenauer Le Souëf, 5 February 1900, 4370A/713/8/11, Le Souëf, WA.

52 Emily Stephen, Gippsland Hospital, Sale, to Vice Chairman, BPA, 23 June 1904, Letters from Aboriginal Women of Victoria: 130.

53 Mr Ditchburn to Emily Stephen, nd, quoted in Letters from Aboriginal Women of Victoria: 130-131. 
While Emily returned to Ramahyuck briefly, in 1905 she was transferred to Lake Tyers, along with most of the remaining residents at Ramahyuck. Whatever the tensions that had existed in her relationship with the Hagenauers, the connection was a significant one for both her and Louise. In 1909, Friedrich Hagenauer died and Emily wrote a letter of sympathy to Louise:

My heart is with you dear, dear Yackan, oh you do not know how I feel. I loved my dear Mongan as though he was my own father. Both you and him have been to me as my own parents, since I came to the Mission a little child only 9 years old. You will have thought that when I came down here I had quite forgotten about you, but it was never so, I could not write because I only would have fretted to go back. As it is I am always thinking of you. I do not talk much about it, but I truly feel a great longing for you it is too sore to talk about ... All your goodness \& kindness is always before me for which I thank you most sincerely. ${ }^{54}$

Emily added, with reference to Ellie, who was visiting from Perth: 'My dearest love to my darling \& her dear little children if they are with her.' If the relationship between Louise and Emily had not been mended before this, Emily's letter appears to have brought about a reconciliation. In the letter, Emily begged to be able to visit 'even if I had to walk ... just to press your dear hands to show my love \& sympathy to you'. ${ }^{55}$ Shortly afterwards, Emily was given permission to travel to Ramahyuck, where Louise was still living, to provide her with emotional and practical support. The two women spent a number of weeks together and Louise gave Emily furniture and other goods from the Hagenauers' house. ${ }^{56}$ In this period of crisis, there is again evidence that on both sides of the relationship, for all its tensions and inequity, there appears to have been real affection.

For Emily, the visit to Ramahyuck appears to have been the catalyst for significant conflict between Emily and the BPA-appointed manager at Lake Tyers, Captain Howe. Howe had recently replaced John and Caroline Bulmer, the Church of England missionaries who had established the mission. When Emily extended her visit to Ramahyuck beyond the permitted two weeks, Captain Howe threatened to have her summoned if she did not return immediately. ${ }^{57} \mathrm{On}$ her eventual return, tensions continued, playing out within the complicated web of relationships at Lake Tyers. Patricia Grimshaw has described elsewhere how Emily had allied herself with the Bulmers, who continued to live at the

54 Emily Stephen to Louise Hagenauer, nd [c.1909], 4370A/479, Le Souëf, WA.

55 Emily Stephen to Louise Hagenauer, nd [c.1909], 4370A/479, Le Souëf, WA.

56 Emily Stephen to Mr Watts, MP, 16 March 1910, Letters from Aboriginal Women of Victoria: 162-163.

57 Stephen to Watts, 16 March 1910. 
mission, providing an alternative source of authority to the Howes. ${ }^{58}$ Emily's youngest daughter, Blanche, worked for the elderly Caroline Bulmer, and when Captain Howe insisted that Blanche should work for his wife instead, Emily wrote repeatedly to members of the BPA to complain. Captain Howe was furious, writing to the BPA: 'Emily Stephen is detrimental to the good order \& discipline of this station ... she practically defies me but in such a manner that I can only make a general complaint, and she goes round all the blacks and the Bulmers telling them that she has the "Board" on her side. ${ }^{59}$ He claimed she had threatened that she would bring about an enquiry into his management and have him removed, a likely reference to the earlier enquiry into Coranderrk reserve, which had resulted in very public criticism of the reserve manager. Emily's use of letter-writing and awareness of the mechanisms of settler society outraged Captain Howe, who fumed 'that is what education has done for her' ${ }^{60}$

At this stage, the members of the BPA refused to agree to Howe's request to transfer Emily, noting that this could not be done where no specific transgression could be proved. However, Howe continued to complain about Emily's defiance and, in June 1911, the BPA received a petition from 22 of the residents at Lake Tyers, asking that Emily be removed from the mission. Emily defended herself, arguing that many of those who signed had no idea what they were signing. Her letter made clear, however, that there were significant tensions between the Aboriginal people who had been moved to Lake Tyers from Ramahyuck and those who had lived there for many years. ${ }^{61}$ Unsurprisingly, forcibly combining these two communities, each drawn in large part from different Aboriginal tribal groups, had created friction. In October 1911, the BPA forced Emily to move again, this time to the Moravian-run mission at Lake Condah, where she was refused permission to return to Lake Tyers to see her children.

In 1914, Emily wrote to the BPA once again, this time from Lake Condah, requesting that she be allowed to move off the mission for good. Though, on her arrival at Lake Condah, she had apparently formed a good relationship with Reverend Stähle, the Moravian missionary manager, Stähle had recently been replaced by a BPA-appointed manager. ${ }^{62}$ By this time, all of Emily's children had reached adulthood. She assured the Board that one of her sons had permanent

\footnotetext{
58 Patricia Grimshaw, 'Colonising motherhood: evangelical reformers and Koorie women in Victoria, Australia, 1880s to the early 1900s', Women's History Review 8(2), 1999: 329-346.

59 R Howe, manager, Lake Tyers, to Mr Ditchburn, 3 April 1911, Letters from Aboriginal Women of Victoria: $167-168$.

60 Captain Howe, Lake Tyers, to Mr Callaway, Vice President, BPA, 9 August 1911, Letters from Aboriginal Women of Victoria: 172.

61 Emily Stephen, Lake Tyers, to Mr Callaway, Vice President, BPA, 26 June 1911, Letters from Aboriginal Women of Victoria: 170-171.

62 The Rev. Stähle wrote repeatedly to the BPA supporting her requests to see her children, but these requests were denied. See Letters from Aboriginal Women of Victoria: 172-173.
} 
work and two of her other children would be able to get employment shortly. The Board revoked the order requiring her to live at Lake Condah, with the proviso that she would no longer receive any financial support. ${ }^{63}$

In the same year that Emily left Lake Condah, Louise Hagenauer reflected on her role at Ramahyuck. Challenged by a sermon on God's guidance, she wrote a brief account of her life in a letter to Ellie. After describing her childhood commitment to the Moravians, the process by which she came to Ramahyuck and her early years there, Louise concluded:

I know the Lord called me, had led \& guided me all my life, saved me from all troubles in many ways - but the Lord who called me expects fruit from my labour - but alas! I have only emptiness \& sin to bring, I have no fruit - I left the great commandment Love out of my labour \& without love you cannot do any good - I only worked \& worked \& left love behind - Oh pray for me dear Ellie that in my last days I may be able to love \& do some good. ${ }^{64}$

In 1917, three years after writing this letter, Louise died. In the same year, Emily's youngest son Gilbert enlisted in the Australian army and departed for England. He became seriously ill during training and shortly after his return to Australia, he too died. ${ }^{65}$ This was one of many hardships that Emily was to experience during the years that followed. In spite of her continual efforts to earn a living, she was forced to write to the BPA on multiple occasions to request temporary rations.

Like her mother, Maud spent much of this period living outside the mission system. Letters that Maud wrote in 1913 show that she and her husband, David Mullett, a former resident of the Coranderrk reserve, were travelling around Victoria for work. Their lives were, however, still restricted by the controls of the BPA, as they had to request permission to visit their relatives at Coranderrk, Lake Condah and Lake Tyers, and at times asked for rations to supplement their earnings. ${ }^{66}$ In 1915, David enlisted in the Australian Imperial Force (AIF) and was not discharged until $1920 .{ }^{67}$ In his absence, Maud initially remained in the Melbourne suburb of Carlton where the couple had been living with their four children. Here she became involved with a Pentecostal religious group, meeting

63 Emily Stephen to Secretary, BPA, 21 March 1914, and Emily Stephen to Captain Crawford, manager, Lake Condah, 10 September 1914, Letters from Aboriginal Women of Victoria: 174.

64 Louise Hagenauer to Ellie Hagenauer Le Souëf, 30 April 1914, 4370A/713/9/4, Le Souëf, WA.

65 Emily Stephen, Dartmoor, to Mr Parker, Secretary, BPA, 24 May 1920, Letters from Aboriginal Women of Victoria: $134-135$.

66 Maud Mullett to Mr John Murray, Chief Secretary, 17 June 1913, Letters from Aboriginal Women of Victoria: 290.

67 National Archives of Australia, Canberra, Australian Imperial Force, Base Records Office, Series no. B2455, First Australian Imperial Force Personal Dossier, 1914-1920. 
at the Good News Hall in North Melbourne. As Patricia Grimshaw has described elsewhere, in 1916 Maud began visiting the Coranderrk reserve, along with women evangelists from the Good News Hall. She encouraged residents of the Coranderrk reserve to visit the Good News Hall, and then suggested holding Pentecostal meetings at the reserve itself. Coranderrk, like most of the other Victorian missions, was by this time no longer run by Christian missionaries, and the manager was horrified by the prospect of such 'disturbing' influences on the reserve. He complained to the BPA after one of Maud's visits: 'Her influence over the natives is very undesirable ... After her departure last night a meeting was again held in one of the cottages and the screams and wails even heard at a great distance. ${ }^{68}$ Maud persisted with her visits, in spite of the manager's disapproval, until in October the BPA responded to his concerns by revoking her permission to visit Coranderrk.

During David Mullett's military service, the BPA had determined that Maud would no longer be eligible for support from the BPA, as she could live off her husband's military pay ${ }^{69}$ Like other Aboriginal people, however, the Mulletts discovered that the equal opportunities apparently offered by service in the AIF were often illusory. The AIF cancelled Maud's allotment, arguing that she should be supported by the BPA. Maud wrote desperately to the BPA, arguing: 'David never inlisted [sic] from the mission[;] we were out earning our living like white people and Sir we have troubled the Government for very little help ... I have been out earning my living ever since I was 19 years of age. ${ }^{70}$ The BPA replied that this was a matter for the Department of Defence and they could not intervene. Facing such inequities, on David's return from service in the Middle East, the Mulletts returned to living at Lake Tyers. ${ }^{71}$

Emily, however, remained determined to maintain some degree of independence, in spite of the difficulty that she and her family had in finding permanent work. She was forced repeatedly to request rations and other supplies from the BPA. Perhaps as a result, in 1918, the BPA offered her and her family the opportunity to move to Lake Tyers. Emily replied on behalf of herself and those of her family who lived with her. After 'thinking very deeply over it', she wrote, they had decided that they 'would all rather battle on out among white people' ${ }^{72}$ While she expressed gratitude for the offer, she stated that it 'was much better to be

\footnotetext{
68 Mr Robarts, manager, Coranderrk, to Mr Ditchburn, Secretary, BPA, 17 July 1916, Letters from Aboriginal Women of Victoria: 230.

69 Mr Robarts, manager, Coranderrk, to Mr Ditchburn, Secretary, BPA, 20 November 1915, Letters from Aboriginal Women of Victoria: 291.

70 Maud Mullett, Hamilton, to Mr Parker, Secretary, BPA, 22 May 1919, Letters from Aboriginal Women of Victoria: 291.

71 Albert Mullett, interview by Lou Bennett, 'Mission Voices', http.//www.abc.net.au/ missionvoices.lake tyers/voices of lake tyers/default.htm, accessed 20 January 2013.

72 Emily Stephen, Clark St, Hamilton, to Mr Parker, BPA, 23 May 1918, Letters from Aboriginal Women of Victoria: 131.
} 
on your own, than among a crowd, especially your own people, further away so much the better' ${ }^{73}$ The family planned to purchase a cheap block of land in Hamilton, erect a house, grow vegetables and find work in the local area. The BPA commended this desire for independence and continued to send her occasional rations, sometimes unasked, in the years that followed. ${ }^{74}$

As a result of Gilbert's death, the Stephen family were eligible to claim various payments from the Department of Defence. Emily's attempts to claim this money reveal something of the nature of her relationship with her husband, Harry Stephen, who is barely mentioned in any of her other correspondence to the Hagenauers or to the BPA. She informed the BPA that she had not lived with Harry since 1914 and that she had never relied on him for financial support, as 'what ever he earned he drank \& gambled \& was so often in Gaol' ${ }^{75}$ Harry was living at Lake Tyers, Emily wrote, where he was cared for and restricted from drinking. She urged the BPA to prevent him from receiving any money from the Department of Defence, as 'he will only squander \& gamble it'.$^{76}$ She was living in the Hamilton region, where her family had nearly finished building their new house. Though she was repeatedly unwell, she wrote of her delight in the location: 'it is lovely out here in the bush[;] we are very lucky to have beautiful fresh water to drink \& use[;] in fact it is spring water clear as crystal \& cool on the hottest day. ${ }^{\prime 77}$

Emily was not able to enjoy her new house for many years. After a long stay in hospital, she died in November 1926. A notice in the local newspaper, inserted by her family, thanked the staff at the hospital for 'their kindness, care and attention' and the Christian Endeavour Society and all other friends 'who in any way helped to cheer her during her long stay in the hospital' ${ }^{78}$

In the 1930s, Maud and David Mullett were moved off the Lake Tyers mission, along with all those Aboriginal people who were judged not to be 'full-blood'. They lived on the fringes of the Lake and travelled around the state attempting to find work. Maud's grandson remembered that in the late 1930s he had visited Melbourne with his grandparents, staying with other Aboriginal people surviving on the fringes of the city.

I remember that quite well - my grandfather carrying me on his shoulder, and down to all these little tin humpies over there near the Westgate

73 Emily Stephen to Mr Parker, 23 May 1918.

74 See Letters from Aboriginal Women of Victoria: 131-135.

75 Emily Stephen, Dartmoor, to Mr Parker, BPA, 24 May 1920, Letters from Aboriginal Women of Victoria: 134-135.

76 Emily Stephen to Mr Parker, 24 May 1920.

77 Emily Stephen, Dartmoor, to Mr Parker, BPA, 9 February 1920, Letters from Aboriginal Women of Victoria: 133

78 Portland Guardian, 15 November 1926: 2. 
Bridge. And there was Koories and non-Koories and I remember walking over the sand hills and the fires were going and I remember that really well. ${ }^{79}$

Though there is no record of any correspondence between Ellie and Emily after 1904, Ellie kept Emily's earlier letters, together with her own diaries from the years at Ramahyuck, suggesting that her connection to Ramahyuck remained an important aspect of her identity. Ellie became a prominent member of Perth society, actively promoting multiple charities while her husband established the Perth Zoo. When she died in 1947, aged 74, notices appeared in newspapers in most of the major state capitals. In Melbourne, the notice in The Argus, inserted by her brothers, described her simply as 'youngest daughter of the late Rev. FA and Mrs Hagenauer, of Ramahyuck Mission Station, Gippsland' ${ }^{80}$

In conclusion, though Ramahyuck Mission was closed in 1908, it shaped the lives of these four women in significant ways. The mission was a profoundly inequitable environment, in which non-Indigenous missionaries wielded the power of the colonial state over Indigenous residents. Emily and Maud were subject to conditions of surveillance and restriction, which aimed to control every aspect of their lives. Louise and Ellie were active in enforcing these conditions, while showing little awareness of the profound injustice and loss that Indigenous people had experienced and continued to experience through colonisation. It is not at all surprising that resentment and conflict were an ongoing part of the interactions between the four women. Yet the situation at Ramahyuck produced a degree of intimacy and inter-dependence between the two mothers and daughters. Louise relied on Emily for both emotional and practical support and Ellie grew up with Emily as her nursemaid. Louise tirelessly nursed the sick and elderly at Ramahyuck, including Emily's family. Ellie wrote of Emily's kindness to her mother and when Friedrich Hagenauer died, Louise sought Emily's support. Emily's letters, written in the familial and religious language that the women shared, speak of affection and intimacy. While her connection to Louise and Ellie undoubtedly offered Emily practical benefits, it would be simplistic to conclude that her motivations were simply strategic. As in many human relationships, real affection could exist alongside condescension, resentment, deception and open conflict.

Emily's and Maud's experiences after their departure from Ramahyuck suggest that these personal relationships continued to influence their engagement with the colonial state. This is particularly true for Emily, whose ongoing connection with the older missionary families proved a source of conflict with the BPA-

79 Albert Mullett, interview by Lou Bennett, 'Mission Voices', http.//www.abc.net.au/missionvoices.lake tyers/voices of lake tyers/default.htm, accessed 20 January 2013.

80 The Argus, 7 August 1947: 9. 
appointed manager at Lake Tyers. Her relationships with these families were also, however, an alternative source of support in the early years of her long battle to gain self-sufficiency and hold her family together. Maud's conflict with the management at Coranderrk demonstrated a similar confidence to oppose the representatives of the colonial state and ability to form connections with non-Indigenous religious activists. Both women used their knowledge of the colonial bureaucracy and the tool of letter-writing, which they had learned at Ramahyuck, to negotiate with the state.

Louise and Ellie, through their roles at Ramahyuck, promoted Christian faith, hard work, self-discipline and self-sufficiency. Though Louise later reflected that her emphasis on work had distracted her from a greater good, Emily and Maud both expressed their strong desire for independence and their conviction that work was the key to this independence. It is ironic that this appears to have been in part a result of their desire to escape the restrictive and conflict-ridden environment of the mission system. Their experience demonstrates how late nineteenth-century policies, enacted through missions, which split Indigenous families, forced diverse communities to live at close quarters, replaced longterm missionaries with a constant series of managers and deprived people of their connections and rights to country, disrupted the possibility of stable communities which could support self-sufficiency. Off the missions, in spite of Emily's and Maud's hard work, perseverance and courage, the broader inequities of settler society made it virtually impossible for them to sustain their independence. The stark contrast between their experience of life after Ramahyuck and that of Ellie Le Souëf is evidence of how colonial governance of Indigenous people undermined the very qualities that it claimed to promote. 
This text is taken from Settler Colonial Governance in Nineteenth-Century Victoria, edited by Leigh Boucher and Lynette Russell, published 2015 by ANU Press and Aboriginal History Inc., The Australian National University, Canberra, Australia. 